\title{
EKSPLORASI KEGIATAN MAHASISWA DALAM ORGANISASI KEMAHASISWAAN DI DEPARTEMEN PENDIDIKAN TEKNIK MESIN UNIVERSITAS PENDIDIKAN INDONESIA
}

\author{
Asep M. Arifin ${ }^{1}$, Wowo S. Kuswana ${ }^{2}$, Tatang Permana ${ }^{3}$ \\ Departemen Pendidikan Teknik Mesin \\ Universitas Pendidikan Indonesia \\ Jl. Dr. Setiabudhi No. 207 Bandung 40154 \\ simkuring007@gmail.com
}

\begin{abstract}
ABSTRAK
Penelitian ini bertujuan untuk mengetahui kondisi organisasi HMM FPTK UPI berdasarkan perspektif anggota dan untuk mengetahui persentase pengaruh aktif berganisasi dengan nilai akademik. Kegiatan kemahasiswaan meliputi aspek pengetahuan keorganisasian, kepemimpinan, manajemen organisasi, cara pengambilan keputusan dan efek pada akademik. Penelitian ini menggunakan metode deskriptif dengan pendekatan kuantitatif. Hasil penelitian menunjukkan bahwa kegiatan organisasi terhadap akademik tidak memberikan efek negatif. Adapun terjadi penurunan nilai akademik, bukan merupakan pengaruh dari kegiatan organisasi. Kegiatan organisasi terhadap nilai akademik berpengaruh positif.
\end{abstract}

Kata kunci: kegiatan, mahasiswa, organisasi, departemen, kepemimpinan

\section{PENDAHULUAN}

Kehidupan kemahasiswaan Universitas Pendidikan Indonesia, baik di tingkat universitas maupun tingkat fakultas dan yang lebih spesifik lagi tingkat departemen, dapat dilihat dari dinamika, aktivitas, dan prestasinya. Organisasi kemahasiswaan intra perguruan tinggi adalah wahana dan sarana pengembangan diri mahasiswa ke arah perluasan wawasan dan peningkatan kecendekiawanan serta integritas kepribadian untuk mencapai tujuan pendidikan tinggi.

Keputusan Menteri Pendidikan dan Kebudayaan Republik Indonesia nomor 155/U/1998, tentang pedoman umum organisasi kemahasiswaan di perguruan tinggi. Perlu kita sadari bahwa organisasi kemahasiswaan merupakan bagian yang tidak terpisahkan dari dari tujuan pendidikan saat ini. Menyiapkan peserta didik menjadi anggota masyarakat yang memiliki kemampuan akademik dan/atau profesional yang dapat menerapkan, mengembangkan dan/atau menciptakan ilmu pengetahuan, teknologi dan/atau kesenian. Mengembangkan dan menyebarluaskan ilmu pengetahuan, teknologi dan/atau kesenian serta mengupayakan penggunaannya untuk meningkatkan tarap kehidupan masyarakat dan memperkaya kebudayaan nasional.

\footnotetext{
${ }^{1}$ Mahasiswa Departemen Pendidikan Teknik Mesin FPTK UPI

${ }^{2}$ Dosen Departemen Pendidikan Teknik Mesin FPTK UPI

${ }^{3}$ Dosen Departemen Pendidikan Teknik Mesin FPTK UPI
} 
Kegiatan kemahasiswaan harus kita pelihara, disesuaikan, dan dikembangkan ke arah yang lebih baik. Sebagai calon pendidik dan pemimpin dimasa depan, mahasiswa harus aktif dan dinamis seraya tetap mempertahankan ciri khasnya, yakni senantiasa peduli dengan fenomena pendidikan IPTEK, dan kemasyarakatan di lapangan (Gibson dan Donnely, 1994). Kegiatan kemahasiswaan merupakan perwujudan dari seperangkat pengetahuan dan keterampilan yang dimiliki dalam rangka mempersiapkan diri memasuki kehidupan masyarakat global yang ditandai dengan kempetisi yang sangat ketat, dengan demikian kita harus mengembangkan kegiatan kemahasiswaan yang dinamis, produktif, dan inovatif.

Sesuai dengan peraturan Rektor Universitas Pendidikan Indonesia nomor 8052/H40/HK/2010, tentang organisasi kemahasiswaan di lingkungan universitas pendidikan Indonesia. Organisasi kemahasiswaan UPI selanjutnya disingkat ormawa upi adalah organisasi yang dibentuk dari, oleh, dan untuk mahasiswa pada tingkat universitas, fakultas, sekolah pascasarjana, departemen/program studi,dan kampus daerah yang merupakan sarana pengembangan penalaran, keilmuan, kewirausahaan, minat dan bakat, pengembangan kesejahteraan mahasiswa, dan pengabdian pada masyarakat.

Ormawa dapat berbentuk badan, himpunan, lembaga, dewan, majelis, forum, unit kegiatan mahasiswa, dan atau nama lain sesuai dengan visi dan misi universitas, ditingkat universitas dapat dibentuk ormawa, sebagai berikut: a) majelis permusyawaratan mahasiswa UPI yang disingkat dengan nama MPM UPI; b)dewan perwakilan mahasiswa UPI yang disingkat dengan nama DPM UPI; c) badan eksekutif mahasiswa UPI yang disingkat BEM UPI; d) unit kegiatan mahasiswa UPI yang disingkat dengan nama UKM UPI; e) forum komunikasi unit kegiatan mahasiswa yang disingkat FK UKM. Disetiap fakultas dapat dibentuk ormawa sebagai berikut : a) majelis permusyawaratan mahasiswa fakultas yang disingkat dengan nama MPM Fakultas; b) dewan perwakilan mahasiswa fakultas yang disingkat dengan nama DPM Fakultas; c) badan eksekutif mahasiswa fakultas yang disingkat BEM Fakultas; d) unit kegiatan fakultas yang disingkat dengan nama UKM Fakultas. Disetiap departemen/program studi dapat dibentuk ormawa sebagai berikut : a) majelis permusyawaratan mahasiswa departemen/program studi; b)dewan perwakilan mahasiswa departemen/program studi; c) badan eksekutif mahasiswa departemen/program studi.

Himpunan Mahasiswa Departemen (HMD) adalah organisasi mahasiswa pada tingkat departemen atau program yang mempunyai nama bervariasi sebagai badan pelengkap organisasi senat mahasiswa fakultas. HMD yang ada di fakultas pendidikan 
teknologi dan kejuruan (FPTK) yaitu Himpunan Mahasiswa Mesin, Elektro, Sipil, Arsitek, PKK, dan Argoindustri.

AD/ART sebagai pedoman organisasi HMM FPTK UPI menjelaskan bahwa HMM FPTK UPI adalah satu-satunya organisasi mahasiswa tertinggi yang sah dan berdaulat yang ada di Departemen Pendidikan Teknik Mesin FPTK UPI. HMM FPTK UPI berazaskan Hexasila yaitu religious, persaudaraan, persamaan, persatuan, kegotongroyongan, dan ilmiah. HMM FPTK UPI bersifat intra Universitas, Independen, Progressif dan Revolusioner.

AD/ART HMM FPTK UPI menyatakan bahwa tujuan sebagai berikut : 1) Membina mahasiswa Departemen Pendidikan Teknik Mesin yang sadar dan bertanggungjawab kepada agama, bangsa, negara dan institusi; 2) Membina profesi keguruan dan keteknikan yang didasari oleh amanat pengamalan Tridharma Perguruan Tinggi; 3) Membina kehidupan kemahasiswaan di Departemen Pendidikan Teknik Mesin FPTK UPI yang kokoh dan penuh dedikasi; 4) Membina kemandirian Mahasiswa Departemen Pendidikan Teknik Mesin Universitas Pendidikan Indonesia yang dapat mengikuti perkembangan ilmu pengetahuan dan teknologi; 5) Menampung dan memperjuangkan aspirasi mahasiswa Departemen Pendidikan Teknik Mesin FPTK UPI.

Berdasarkan hasil kajian laporan pertanggungjawaban ketua HMM FPTK UPI, serta hasil wawancara ketua HMM FPTK UPI periode 2014-2015. Ada beberapa masalah diantaranya anggota kurang rasa memiliki terhadap organisasi, serta belum tercapainya tujuan organisasi, dan penyelesaian studi yang kurang tepat. Hal tersebut mengakibatkan kurang maksimalnya kinerja organisasi (Wibisono, 2006). Untuk itu peneliti ingin mengetahui seberapa besar persentase pendapat anggota HMM FPTK UPI mengenai kondisi organisasi, dan akademik pengurus HMM FPTK UPI.

\section{METODE PENELITIAN}

Metode penelitian merupakan suatu cara atau langkah-langkah yang harus ditempuh dalam kegiatan penelitian agar pengetahuan yang akan dicapai dari suatu penelitian dapat memenuhi harga ilmiah. Penelitian ini bertujuan mendapatkan gambaran secara sistematis dan akurat mengenai fakta sifat-sifat dan hubungan antar fenomena yang diamati yang sedang berlangsung saat ini. Metode yang digunakan dalam penelitian ini adalah metode deskriptif menggunakan pendekatan kuantitatif. Data yang dikumpulkan mula-mula disusun, dijelaskan dan kemudian dianalisa. 
Desain penelitiaan merupakan rencana atau tahapan dalam penelitian yang akan dilakukan. Studi pendahuluan dilakukan untuk mengetahui apa yang diperlukan untuk menyelesaikan masalah yang terjadi. Populasi yang diambil dalam penelitian ini adalah mahasiswa Departemen Pendidikan Teknik Mesin FPTK UPI angkatan 2012 yang sedang menjadi penanggung jawab HMM FPTK UPI yang berjumlah 134 orang. Penentuan jumlah sampel dalam penelitian ini adalah semua pengurus HMM FPTK UPI angkatan 2014-2015 yaitu ada 35 orang. Instrumen yang digunakan dalam penelitian ini adalah, lembar wawancara, dan angket (kuisioner).

Analisis data merupakan tahapan dalam mengolah data hasil penulisan berdasarkan variabel yang diteliti ke dalam bentuk persentase yang selanjutnya akan dideskripsikan, sehingga data tersebut dapat dibuat ke dalam uraian lebih rinci, jelas, sistematis, dan dapat dipercaya. Penyajian data dalam bentuk tabel atau distribusi frekuensi dan tabulasi silang (crosstab).

\section{HASIL PENELITIAN}

Hasil penelitian tentang keorganisasian dari semua responden $13,21 \%$ menyatakan sangat memahami tentang keorganisasian, 53,21\% menyatakan memahami tentang keorganisasian, $28,57 \%$ menyatakan biasa-biasa saja dalam pemahaman terhadap organisasi , 4,64\% menyatakan kurang dalam pemahaman organisasi, 0,36 menyatakan tidak memahami tentang organisasi. Secara keseluruhan responden sudah paham dan setuju bahwa organisasi HMM FPTK UPI sudah sejalan dengan AD/ART serta dengan keinginan anggota.

Mayoritas responden menyatakan bahwa kegiatan organisasi HMM FPTK UPI sudah sejalan dengan tujuan dan keinginan anggota, dapat ditinjau dari program kerja yang terlaksana. Beberapa program kerja HMM FPTK UPI antara lain, kaderisasi, P2M (pengabdian pada masyarakat), serta program lainnya yang bertujuan untuk megembangkan potensi dan kemampuan yang dimiliki anggota. Dilihat dari aspek hak dan kewajiban, tugas dan wewenang serta aturan keanggotaaan HMM FPTK UPI responden sudah memahami hal itu. Hal ini maksudnya bahwa anggota dan pengurus telah menjalankan roda organisasi sesuai dengan kaidah dan peraturan yang berlaku. Tentu saja hak dan kewajiban adalah salah satu aspek yang sangat vital terhadap jalannya organisasi. Ketua umum sebagai nahkoda organisasi menjadi tumpuan utama terhadap jalannya roda organisasi. Begitu juga dengan anggota yang seharusnya dapat melaksanakan tugas/instruksi dari ketua. Ditinjau dari hasil penelitian maka dapat dijelaskan bahwa 
responden memiliki kedalaman pemahaman yang cukup baik tentang pengetahuan keorganisasian HMM FPTK UPI.

Data hasil penelitian tentang Kepemimpinan dari semua responden 23,57\% menyatakan kepemimpinan di HMM FPTK UPI sangat baik, 61,43\% menyatakan kepemimpinan baik, 15\% menyatakan kepemimpinan di HMM FPTK UPI biasa-biasa saja. Secara keseluruhan responden sudah paham dan setuju bahwa kepemimpinan di organisasi HMM FPTK UPI sudah sejalan dengan AD/ART serta kaidah-kaidah kepemimpinan. Mayoritas responden menyatakan bahwa kepemimpinan di organisasi HMM FPTK UPI sudah sejalan dengan tujuan dan keinginan anggota, dapat ditinjau dari program kerja yang terlaksana. Kepemimpinan yang baik memiliki beberapa aspek ideal, yaitu persepsi sosial, kemampuan berpikir abstrak, keseimbangan emosional. Hasil penelitian menjelaskan bahwa anggota sudah merasa setuju dan puas dengan kinerja ketua umum. Dilihat gaya kepemimpinan ketua HMM FPTK UPI, responden dinilai sudah setuju dengan gaya kepemimpinan ketua umum HMM FPTK UPI. Ditinjau dari kepemimpinan serta gaya kepemimpinan ketua HMM FPTK secara keseluruhan anggota telah merasa Ketua HMM FPTK UPI sudah cukup memenuhi kriteria ketua umum yang baik.

Data hasil penelitian tentang Manajemen Organisasi HMM FPTK UPI dari semua responden $13,21 \%$ menyatakan sangat memahami manajemen organisasi, 57,50\% menyatakan memahami manajemen organisasi, 23,93\% menyatakanbiasa-biasa saja dalam pemahaman organisasi, 4,64 \% menyatakan kurang memahami manjemen organisasi , 0,71\% menyatakan tidak memahami manajemen organisasi.

Secara keseluruhan responden sudah paham dan setuju bahwa manajemen organisasi HMM FPTK UPI sudah sejalan dengan AD/ART serta dengan keinginan anggota. Mayoritas responden menyatakan bahwa program kerja di organisasi HMM FPTK UPI sudah sejalan dengan tujuan dan keinginan anggota, dapat ditinjau dari program kerja yang terlaksana. Program kerja adalah agenda kegiatan yang tahunan yang dirancang pengurus. Hal ini adalah factor vital dari jalannya roda organisasi. Setiap organisasi memiliki ciri khas program kerja sesuai dengan bidang yang digeluti. Dalam hal ini organisasi yang memiliki nilai jual untuk sponsorship, dan sangat relevan dengan bidang yang menjadi focus kegiatan.

Dilihat dari aspek manajemen SDM dan manajemen kegiatan HMM FPTK UPI responden sudah memahami hal itu. Aspek manajemen SDM anggota mayoritas merasa sudah merasa setuju. Terlihat dari pengkaderan SDM secara formal maupun secara informal, upgrading anggota atau pengurus, dan penempatan SDM yang sesuai dengan 
kompetensi dan kemampuannya. Ditinjau dari aspek manajemen kegiatan aggota pun kebanyakan merasa puas dengan manajemen kegiatan walaupun dalam pelaksanaan teknis selalu terjadi beberapa masalah, namun dapat segera diselesaikan. Hal ini menyebabkan ada beberapa responden yang kurang setuju dengan manajemen kerja dan manajemen SDM yang terjadi di HMM FPTK UPI.

Data hasil penelitian tentang Akademik Pengurus HMM FPTK UPI dari semua responden 22,38\% menyatakan berkegiatan di HMM FPTK banyak manfaatnya dan sangat mendukung terhadap akademik. Sebanyak 37,14\% menyatakan berkegiatan di HMM FPTK UPI bermanfaat dan mendukung terhadap akademik. Sebanyak 28,57\% menyatakan berkegiatan di HMM FPTK UPI ada manfaatnya dan biasa-biasa saja terhadap akademik. Sejumlah 6,19\% menyatakan berkegiatan di HMM FPTK UPI kurang bermanfaat dan kurang mendukung terhadap akademik. Sebanyak 5,71\% menyatakan berkegiatan di HMM FPTK UPI tidak ada manfaatnya dan tidak mendukung terhadap akademik.

Mayoritas responden menyatakan bahwa berkegiatan di organisasi HMM FPTK UPI banyak manfaatnya dan dapat mendukung nilai akademik, dapat ditinjau banyaknya nilai akademik responden yang mengalami peningkatan. Dapat dijelaskan bahwa 46\% responden mengalami peningkatan dalam nilai akademik. Sebanyak $20 \%$ tidak mengalami peningkatan nilai akademik, dan 34\% mengalami penurunan nilai akademik. Dilihat dari hasil yang didapat terjadi pasang surut nilai akademik, nilai akademik yang mengalami peningkatan tidak terlalu jauh, dan yang mengalami penurunan nilai akademik tidak terlalu jauh juga. Hasilnya bisa dilihat dengan nilai akademik terendah sebelum jadi pengurus yaitu 2,35 dan nilai akademik tertinggi yaitu 3,52. Setelah jadi pengurus HMM FPTK UPI nilai akademik terendah adalah 2,4 dan nilai akademik tertinggi yaitu 3,52. Berarti ada peningkatan walaupun itu kecil, maka dari itu ternyata hidup berorganisasi memberikan nilai positif bagi mahasiswa, terutama yang jadi pengurus HMM FPTK UPI.

\section{PEMBAHASAN}

Penelitian ini pada dasarnya memiliki fokus untuk mendeskripsikan tingkat kegiatan mahasiswa dalam organisasi kemahasiswaan di Departemen Pendidikan Teknik Mesin Fakultas Pendidikan Teknologi Dan Kejuruan Universitas Pendidikan Indonesia. Penelitian ini dilakukan untuk mengetahui kondisi organisasi HMM FPTK UPI dan dapat digunakan sebagai referensi untuk kemajuan dan perkembangan organisasi tersebut. Pembahasan data pada penelitian ini dilakukan dengan mengacu kepada rumusan masalah dan kajian pustaka serta data informasi yang telah dipaparkan sebelumnya. 
Tingkat kegiatan mahasiswa secara keorganisasian dan akademik di Departemen Pendidikan Teknik Mesin saling berkesinambungan. Secara keorganisasian dapat ditinjau menjadi beberapa aspek, diantaranya Keorganisasian HMM FPTK UPI, Kepemimpinan HMM FPTK UPI, dan Akademik. Keorganisasian HMM FPTK UPI meliputi visi dan misi, tujuan organisasi, dan struktur organisasi. Pada aspek ini secara keseluruhan responden menyatakan bahwa organisasi HMM FPTK UPI dilihat dari visi dan misi, tujuan organisasi, dan struktur organisasi sudah sejalan dengan AD/ART dan keinginan anggota. Ditinjau dari aspek kepemimpinan, HMM FPTK UPI memiliki ketua/pimpinan yang bisa mengontrol anggotanya, memiliki kebijakan yang jelas, dan memiliki tingkat popularitas yang cukup. Ditinjau dari aspek manajemen organisasi, keterlaksanaan program kerja HMM FPTK UPI sudah mendapatkan dukungan dari anggota dan lembaga UPI, walaupun masih ada kekurangan dalam pelaksanaan teknis, secara pengelolaan program kerja dan kegiatan HMM FPTK UPI sudah sesuai dengan rencana dan strategi yang dibuat pada tahap perencanaan yang dilaksanakan anggota dan pengurus, program kerja dianggap sudah tersosialisasikan dengan baik terhadap anggota (Wursanto, 2003).

Suatu organisasi harus memiliki anggota minimal dua oran yang bekerja sama untuk mencapai suatu tujuan tertentu dengan cara-cara tertentu. Suatu organisasi yang baik, pasti memiliki jumlah anggota yang jelas dan identitas yang jelas. Misalnya dalam suatu perekrutan, telah terpilih anggota sebanyak 50 orang, dan masing-masing anggota ditandai dengan suatu surat keputusan atau pun kartu tanda anggota. Serta mempunyai aturan dalam perekrutan anggota yang jelas.

Suatu organisasi yang baik memiliki identitas yang jelas, seperti namanya, latar belakang berdirinya, anggaran dasar/anggaran rumah tangga, bergerak di suatu bidang tertentu, dan alamatnya jelas serta lambang organisasi yang jelas. Di dalam organisasi yang baik, terdapat suatu struktur yang memiliki pembagian dan tugas yang jelas. Paling tidak terdapat ketua, sekretaris, dan masing-masing divisi. Sehingga dalam organisasi tersebut jelas arah koordinasinya. Manajemen organisasi sekurang-kurangnya memiliki Planning (perencanaan), langkah-langkah yang akan diambil dengan suatu pertimbangan yang matang, kemudian Action (aksi), pelaksanaan dari sesuatu yang telah direncanakan sebelumnya, kemudian yang terkakhir yaitu Evaluation (evaluasi), penilaian terhadap kekurangan-kekurangan yang telah terjadi pada tahap pelaksanaan, serta ditemukannya solusi agar ke depannya bisa semakin baik dan berkembang. Tiga hal tersebut yang digunakan dalam setiap pelaksanaan suatu program kerja. 
Organisasi yang baik tidak hanya memberikan keuntungan dan manfaat bagi anggota-anggotanya, tapi juga memberikan manfaat yang positif bagi lingkungan, suatu organsasi dilihat baik bukan dari internalnya saja, tetapi dilihat dari segi eksternal juga, misalnya himpunan mahasiswa mesin, menyelenggarakan pelatihan service sepeda motor kepada pemuda putus sekolah, dengan tujuan membantu memberikan keterampilan dalam keteknikan, untuk menjadi modal hidup kedepannya, dari program tersebut organisasi dapat diterima dan diakui oleh masyarakat disekitarnya.

Keberhasilan suatu organisasi dilihat dari visi dan misi, tujuan, dan struktur organisasi bisa dilihat bahwa organisasi tersebut memiliki pandangan jauh yang jelas kedepannya, dan diinplementasikan dalam beberapa program untuk mencapai visi tersebut, dalam pelaksanaanya perlu adanya, rencana strategik, rencana tahunan, program tahunan jangka pendek. Himpunan mahasiswa mesin FPTK UPI sudah memiliki visi dan misi, tujuan, dan struktur yang jelas yang tertuang dalam AD/ART dan memiliki rencana program yang jelas yang tertuang dalam Garis Besar Program Kerja(GBPK). Namun dalam pelaksanaanya masih mengalami banyak hambatan dalam pelaksanaanya (Winardi, 2009).

Pemimpin yang baik idealnya harus memiliki inteligensi yang tinggi dan pendidikan umum yang luas, bersifat ramah tamah dalam tutur kata, sikap, dan perbuatan, berwibawa dan memiliki daya tarik, sehat jasmaniah maupun rohaniah (fisik maupun mental). Selain itu, memiliki kemampuan analistis, memiliki daya ingat yang kuat, mempunyai kapasitas integratif, keterampilan berkomunikasi, keterampilan mendidik, personalitas dan objektivitas, jujur terhadap diri sendiri, atasan, bawahan, sesama pegawai (Winardi, 2007). Dilihat dari sudut pandang responden, pemimpin/ketua HMM FPTK UPI sudah baik dilihat dari segi tugas yang dijalankan sudah baik, memiliki syarat kepemimpinan yang baik, memiliki gaya dang kebijakan yang sesuai dengan keingginan anggota, serta bisa mengontrol jajaran pengurusnya.

Manajemen adalah seni melaksanakan dan mengatur. Manajemen secara universal belum memiliki difenisi yang tepat dan dapat diterima. Seorang manajer bertugas mengatur dan mengarahkan orang lain untuk mencapai tujuan organisasi. HMM FPTK telah mengatur program kerja, anggota dan kegiatannya (Wahjono, 2010).

Manajemen kegiatan meliputi planning (perencanaan), organizing (pengorganisasian), actuating (pelaksanaan), controlling (pengawasan), HMM FPTK UPI dalam keterlaksanaan program kerja responden menyatakan sebagian besar program terlaksana. Program yang dijalankan sudah sesuai dengan AD/ART dan keinginan anggota. 
Namun masih jauh dari kata sempurna karena masih banyak kekurangan, yakni belum maksimalnya manajemen kegiatan yang dilakukan, serta anggota merasa kurang memiliki terhadap organisasi, dan belum maksimalnya dukungan dari lembaga UPI terhadap program yang direncanakan (Sopiah, 2008). Dari segi perencanaan sudah matang, dalam pengorganisasian sudah bagus, namun dalam pelaksanaan yang masih kurang, dan dalam pengontrolan juga masih kurang.

Manfaat berorganisasi diantaranya memperluas pergaulan diantara mahasiswa maupun dengan masyarakat luas, meningkatkan wawasan/pengetahuan. Membentuk pola pikir yang lebih baik, mengasah mental yang kuat dalam menghadapi masalah dalam kehidupan (Munir, 2012). Meningkatkan kemampuan berkomunikasi, melatih kepemimpinan, belajar manajemen waktu, memperluas jaringan (networking), mengasah kemampuan sosial, dan ajang latihan dunia kerja yang sesungguhnya. Melihat dari manfaat berorganisasi seharusnya semua anggota yang masuk didunia organisasi bisa melihat positif. Dilihat nilai akademik pengurus HMM FPTK UPI beberapa ada yang mengalami peningkatan. Ada yang nilainya akademiknya tetap, dan ada juga yang mengalami penurunan. Sebelum menjadi pengurus HMM FPTK UPI indek prestasi (IP) yang tertinggi mencapai 3,5. Sedangkan Indeks Prestasi terendah yaitu 2,25. Setelah menjadi pengurus ada sebagian mahasiswa yang IP nya mengalami pasang surut, IP tertinggi dengan mencapai 3,52. Sedangkan IP terendah 2,44. Dilihat dari pasang surutnya IP, maka pengurus HMM FPTK UPI memiliki nilai yang bagus, karena IP mereka rata-rata naik.

\section{KESIMPULAN}

Penelitian ini dapat disimpulkan bahwa tingkat kegiatan kemahasiswaan HMM FPTK UPI dapat dijelaskan dalam aspek pengetahuan keorganisasian, kepemimpinan, manajemen organisasi dan berpengaruh pada akademik. Secara umum pengaruh kegiatan organisasi terhadap akademik tidak memberikan efek negatif. Adapun terjadi penurunan nilai akademik tidak berpengaruh signifikan. Kegiatan organisasi terhadap nilai akademik berpengaruh positif.

\section{DAFTAR PUSTAKA}

Gibson, I. dan Donnely. (1994). Organisasi dan Manajemen. Jakarta: Erlangga.

Munir, B. (2012). Six Dimensions Organization. Yogyakarta: Graha Ilmu.

Sopiah, (2008). Perilaku Organisasional. Yogyakarta: Andi Ofset. 
Wahjono, S. (2010). Perilaku Organisasi. Yogyakarta. Graha ilmu.

Wibisono, D. (2006). Manajemen Kinerja. Jakarta. Erlangga.

Winardi, J. (2007). Teori Organisasi dan Pengorganisasian. Jakarta. Rajawali Pers.

Winardi, J. (2009). Manajemen Perilaku Organisasi. Jakarta. Kencana Media Group. Wursanto, (2003). Dasar-dasar Ilmu Organisasi. Yogyakarta. ANDI Yogyakarta. 